\title{
STS Gene
}

National Cancer Institute

\section{Source}

National Cancer Institute. STS Gene. NCI Thesaurus. Code C75584.

This gene plays a role in synthesis of steroids during pregnancy. 